\title{
SEASONAL AND MULTIANNUAL DYNAMICS OF SEDEN- TARY SPECIES POPULATIONS OF HUNTING INTEREST
}

\author{
Anatol Savin, Oleg Ciocoi, Mihail Șcerbliuc, Gheorghe Grosu, Victoria \\ Nistreanu
}

\author{
Instite of Zoology, Chișinău, R. Moldova, e-mail: savin.an1948@mail.ru
}

\begin{abstract}
The aim of the research was to study the number dynamics of the populations of dominant sedentary species of hunting interest as a theoretical context in arguing sustainable measures for the management of economic interest fauna. The studies between 2000-2021 shows that after a period of depression in the populations of sedentary species of hunting interest in 2004-2012 there is an increase from 2016-2017 till present of reproductive stocks in all studied species on average by $95 \%$. The losses in the cold period of the year varied depending on the climatic conditions of the cold period of the year, as well as the age structure at the end of the reproductive period: for the hare between $14 \%$ and $30 \%$, with an average of $23 \%$; in grey partridge from $56 \%$ to $71 \%$ and in pheasant they fluctuate between $48 \%$ and $56 \%$ of the autumn number, being lower in warm winters $(37 \%)$. Analyzing the dynamics of annual increases in sedentary small game species in different climatic conditions, it was found that arid conditions during nesting and offspring growth, decrease annual increases by $143 \%$ in pheasants, $122 \%$ in hares, and only $74 \%$ in partridges, which is a species less dependent on aridizations in the vegetative period.
\end{abstract}

\section{Introduction}

The number of game species, which fully capitalize on the support capacity of the hunting ground with an ecologically balanced demographic structure, without impact on the ecosystem is determined as the optimal number. The optimal number of each species varies cyclically in the conditions of keeping unchanged the regime offered by the hunting fund. The amplitude of the variation of the number of individuals is determined, on the one hand by the biological parameters of the species (reproduction age, annual reproductive potential, longevity, etc.), and on the other hand by the degree of ecological comfort within ecosystems, mainly trophic and disturbance, including predation pressure $[3,5]$. The mechanism of biological cycles takes place against the background of the trophic factor and the influence of climatic factors [6, 7]. Abundant food, accompanied by favorable climatic conditions (mild winters) causes resistant individuals, high fertility (increased number of juveniles, possibly several annual lots), favorable conditions for raising new-born individuals, increased annual growth, low juvenile mortality, leading to a population in qualitative and quantitative ascent, until it reaches the maximum density that the land can support [2,4]. The task of hunting management is to ensure the density of game species as close as possible to the optimal one, counteracting by biotechnical measures any oscillation of the real density, which brings the populations of the species to extreme limits. The problems of managing the non-forested hunting funds are related to the ecology of agricultural ecosystems and solving them will raise the hunting productivity by building an agrosystem on ecological principles [4]. The study of the population dynamics of the species of economic importance will serve as scientific support in their sustainable management. 


\section{Materials and methods}

In order to achieve the objectives, research methods were used related to the characteristic of structural ecological indices: the method of routes, the method of sampling, the method of direct observations; the method of detecting the traces of vital activity; density index method; the method of visualizing the images captured with the help of photo or video cameras, the method of evaluations in open field with the use of night vision devises. The studies were carried out in districts from the southern, northern and central parts of the republic, sample plots were selected in ecotone areas of different ecosystems (forest, aquatic and paludous, meadows, rocky sites, forest belts, localities), and in the adjacent habitats - agrocenoses, forest ecosystems with different degrees of heterogeneity and anthropic activity. For the characteristic of the biotopic distribution of the species, the frequency index was used $\mathrm{F}=100 \mathrm{p} / \mathrm{P}$, where $\mathrm{P}$ - the number of samples, $\mathrm{p}$ - the samples in which the species is present; and the dominance of the species $\mathrm{D}=100 \mathrm{n} / \mathrm{N}$, where $\mathrm{n}$ - the number of individuals of a species in the sample, $\mathrm{N}$ - the total number of individuals from all species, both indices are expressed as a percentage. In order to highlight the position of the species or taxonomic group in the biocenosis, the ecological significance (WA) was calculated according to the formula $\mathrm{Wa}=\mathrm{Fa} \cdot \mathrm{Da} / 100$, where $\mathrm{Fa}$ - group frequency and $\mathrm{Da}$ - abundance index. Taxonomic species or groups with a significance of up to $1 \%$ in the analyzed cenoses are considered accidental; $1.1-5 \%$ - accessorial; $5.1-10 \%$ - characteristic and $\mathrm{Wa}>10 \%$ - constant for the characterized biocenosis.

The statistical and factorial analysis, graphical interpretation of the results was performed using the Microsoft Excel and Statistics programs.

\section{Results and discussions}

The study of the dynamics of autumn number and reproductive stocks in the European hare (Lepus europaeus) population - the main game species in open lands, during the population cycle (2012 - 2021) allowed to establish a year to year increase in spring number with variations between 2.8 and $42 \%$, as well as in autumn number from - 4.5 to $34 \%$ (fig. 1 ; tab. 1).

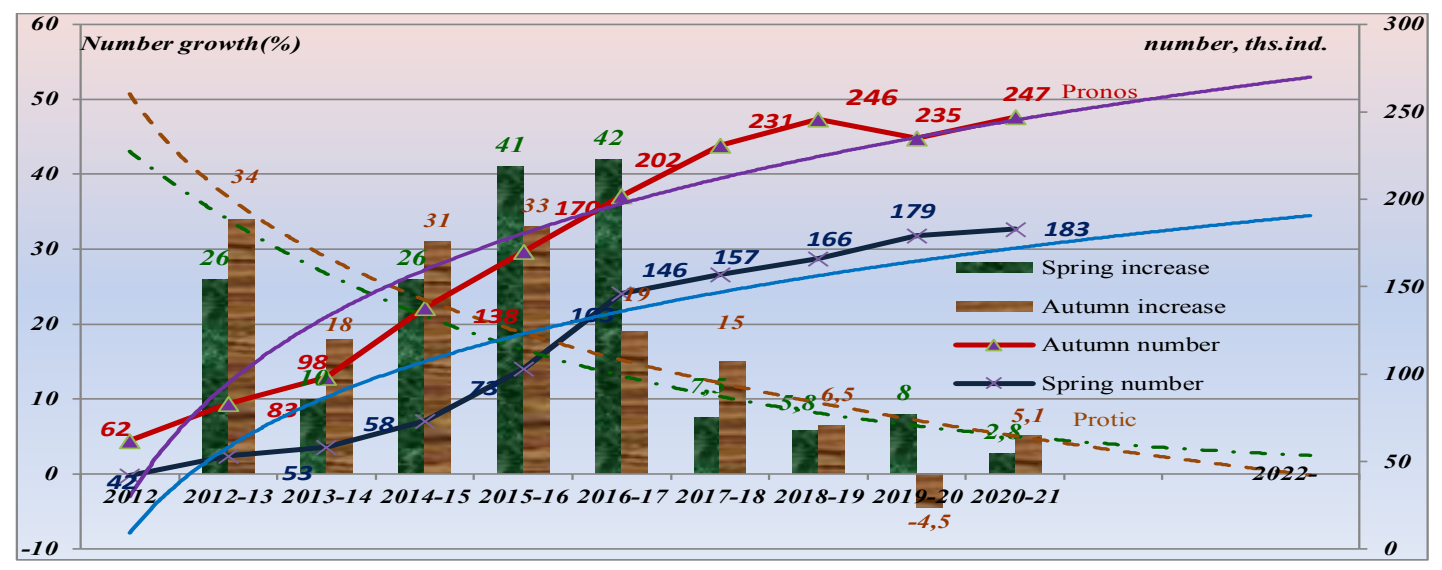

Figure 1. Dynamics of spring and autumn number annual increase during the populational cycle of 2012-2021 and development trends for the next years in European hare populations 
The number increase in spring and autumn is much higher (29 and 27\% respectively) at the initial stages of the population cycle and decrease considerably (4.8 and 5.5\% respectively), with negative values (-4.5\%) in autumn 2020 (with drastic arid conditions), when the population reaches maximum values, approaching the support capacities of agricultural ecosystems for the hare. The trend lines of the numbers and the inter-annual numerical increase in the hare, during the population cycle, allowed to predict in the following years a decrease of both the spring and the autumn increase resulting in a slower growth and even stopping it in the following years.

Table 1. Dynamics of populational parameters during the population cycle of 2012-2021 in hare in agrarian ecosystems of the $R$. Moldova

\begin{tabular}{|l|c|c|c|c|c|c|c|c|c|c|}
\hline \multirow{2}{*}{ Population parameter } & \multicolumn{9}{|c|}{ Period } \\
\cline { 2 - 12 } & 2012 & 2013 & 2014 & 2015 & 2016 & 2017 & 2018 & 2019 & 2020 & 2021 \\
\hline $\begin{array}{l}\text { Spring number } \\
\text { (thousand ind.) }\end{array}$ & 42 & 53 & 58 & 73 & 103 & 146 & 157 & 166 & 179 & 183 \\
\hline $\begin{array}{l}\text { Autumn number } \\
\text { (thousand ind.) }\end{array}$ & 62 & 83 & 98 & 128 & 170 & 202 & 231 & 246 & 235 & 247 (progn.) \\
\hline $\begin{array}{l}\text { Annual reproductive } \\
\text { growth (\%) }\end{array}$ & $\mathbf{4 8}$ & $\mathbf{5 7}$ & $\mathbf{6 9}$ & $\mathbf{7 5}$ & $\mathbf{5 9}$ & $\mathbf{3 8}$ & $\mathbf{4 8}$ & $\mathbf{4 8}$ & $\mathbf{3 1}$ & $\mathbf{3 5 ( p r o g n . )}$ \\
\hline Spring increase* (\%) & & 26 & 10 & 26 & 41 & 42 & 8 & 7,5 & 8 & 2,8 \\
\hline Autumn increase* (\%) & & 34 & 18 & 31 & 33 & 19 & 15 & 6,5 & $-4,5$ & 5,1 (progn.) \\
\hline Winter loss (\%) & & 15 & 30 & 29 & 19 & 14 & 22 & 28 & 28 & 23 \\
\hline
\end{tabular}

Losses in the cold period of the year varied, depending on the climatic conditions of the cold period and the age structure at the end of the reproductive period, between $14 \%$ and $30 \%$, with an average of $23 \%$. The most considerable winter losses $(29,30 \%)$ were observed in the winters of 2014-2015 when the annual reproductive growth was maximum (69.75\%) provided by the summer-autumn generations. In the autumn populations these years young specimens dominated and most of them do not survive until the beginning of the hunting season (December). Significant losses (17.5\% of the autumn population) in October-December of the years 201920 were caused by the unfavorable climatic conditions, which also activated the parasitic and viral impact. As a result of the examination of the coprological samples it was found that the extent of the invasion in the hare (Lepus europaeus) is with Trichocephslus leporis is of 14,2\%, Fasciola hepatica - 8,2\%, Dicrocoelium lanceolatum-18,6\%, Strongyloides papillosus-21,4\%, with oocysts of Eimeria stiedai de 42,2\% and Eimeria perforans de 34,6\%. Climatic conditions in the reproductive period strongly determine the annual increase and the age structure of this increase, estimated on average over the cycle at $51 \%$. At the same time, winter conditions, the biotopic structure of the hunting fund with trophic conditions, shelter, parasitic pressure, the presence of predators $[3,5]$ and poaching [1] are the determining factors of the annual increases, of the demographic structure of the autumn population and of the reproductive stock.

Analyzing the multiannual dynamics of the reproductive number of the partridge population (Perdix perdix) in the agrarian ecosystems of the republic during 2000-2021 it was found that during the years 2004-2010, due to a series of ecological and anthropic conditions, the species 
number began to decrease, reaching the minimum levels (12.8 thousand birds) with densities between 2 and 4 pairs per 1000 ha (fig.2). After the numerical increase (79\%) of 2017, the reproductive stock of partridge is maintained at 43-55 thousand pairs with a slight upward trend in the next years.

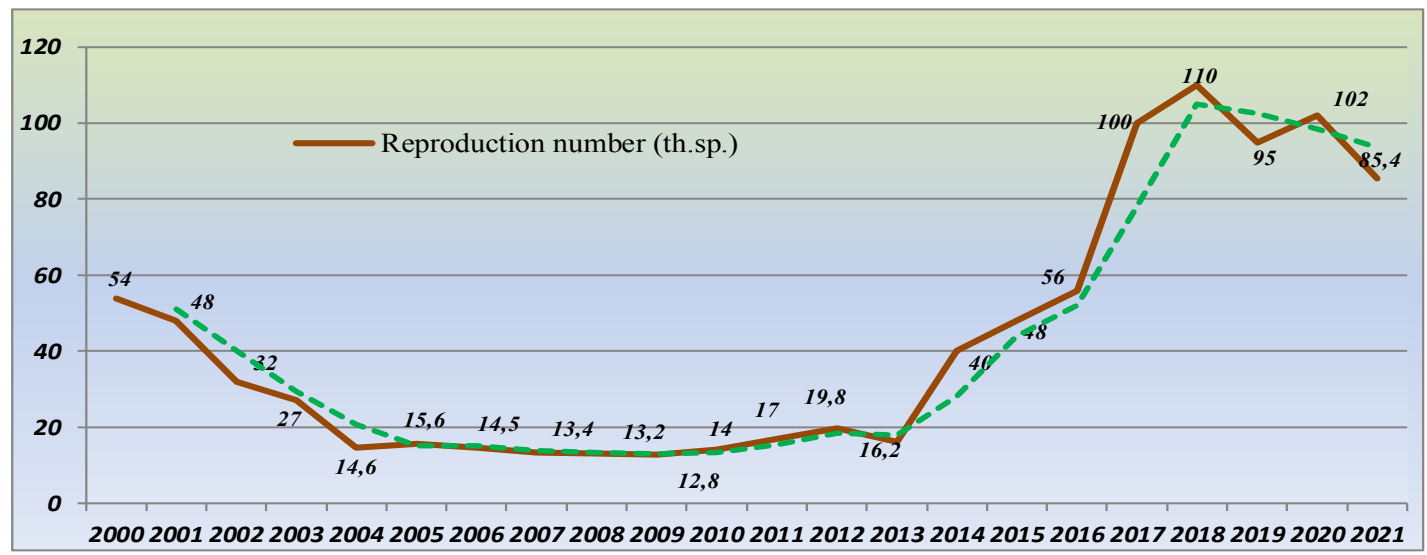

Figure 2. Multiannual dynamics (2000-2021) and the trend of reproductive number in partridge population in the following years

The analysis of the annual dynamics of the partridge number in the last four years showed that the annual increase can reach $270 \%$ of the breeding population with an average of $172 \%$, and the most significant losses start in autumn (October - November) with 45\% from the number at the beginning of October. During the hunting season for hare (November-December) the partridge population loses other $16.8 \%$ (fig. 3).

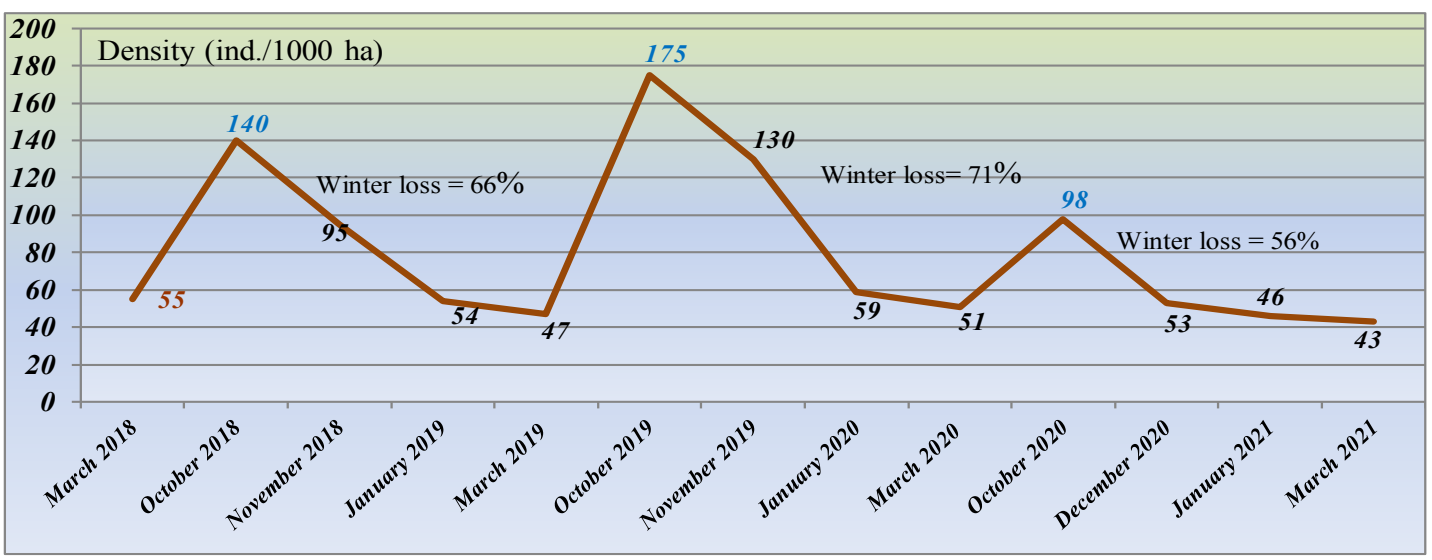

Figure 3. Annual dynamics of partridge density (ind./1000 ha) in agricultural ecosystems during 2018-2021 
In winter, the specimens remain more resistant and viable and the losses for the period January-February constitute on average only $9.5 \%$ of the winter population. Thus, the partridge population in the cold period of the year usually suffers losses that can exceed $71 \%$ of the estimated number in autumn.

The distribution of sedentary species of small game (hare and partridge) during the winter prove that the hare is a constantly encountered species (WA $=12.4-23.8 \%$ ) in multiannual crops (vineyards, orchards), fallow grounds and autumn plowed lands, being characteristic $(\mathrm{WA}=5.8 \%)$ on pastures and hayfields. The partridge has constant ecological significance in fallow ground $(\mathrm{WA}=16.2 \%)$, in pastures and hayfields $(\mathrm{WA}=12.1 \%)$; it is characteristic (WA $=9.3 \%)$ in multiannual crops and accessorial plowed lands $(\mathrm{WA}=4.7 \%)$.

Evaluating the dynamics of the pheasant population (Phasianus colchicus) during the last 6 years can be observed an increase in the dynamics of the species acclimatization process due to the protection measures in the cold period of the year, adequate extraction quotas and annual increase, and permanent completion of the population with pheasants from farms (fig. 4). The decrease in the dynamics of the annual autumn growth also shows that the pheasant is close to reach the maximum possible number for the current support capacity of the pheasant populated biotopes.

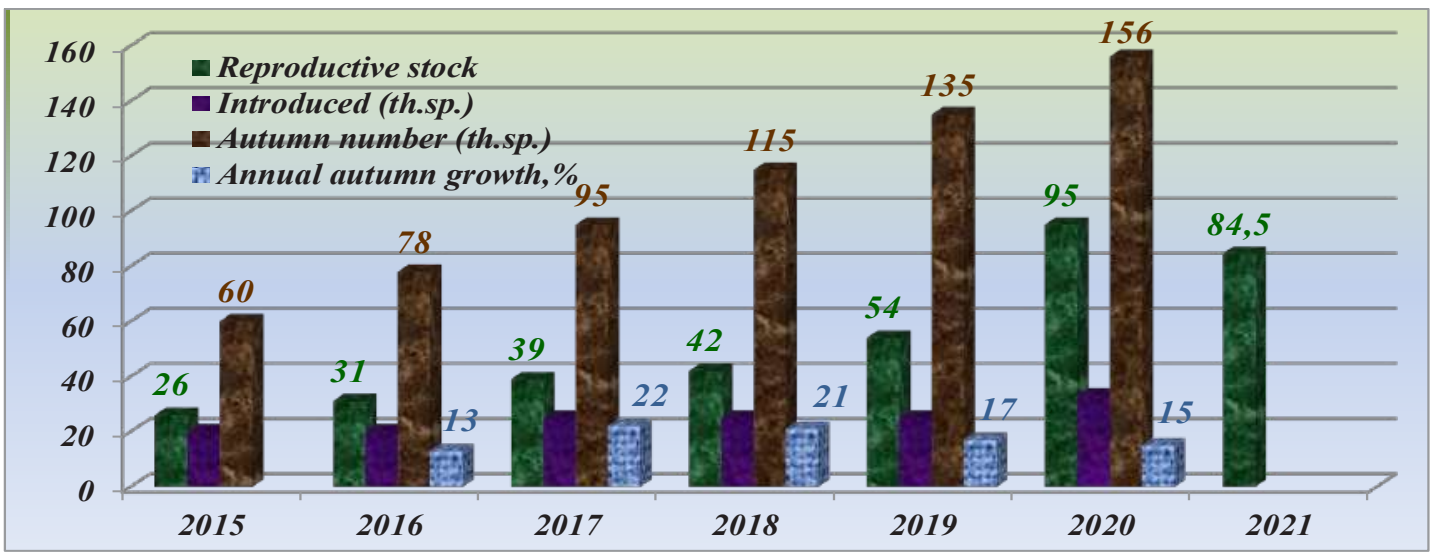

Figure 4. Multiannual dynamics of the population parameters of the pheasant in the acclimatization process

The annual increases, during the evaluated period, due to the climatic conditions during the reproductive period, ranged between 37\% (under stressful arid conditions) and 103-126\% under favorable conditions. The losses in the cold period of the year fluctuate between $48 \%$ and $56 \%$ of the autumn number, being much lower in warm winters $(37 \%)$.

The dynamics analysis of annual increases in sedentary small game species in different climatic conditions showed that arid conditions, during nesting and offspring growth, decrease the annual increases by $143 \%$ in pheasant, $122 \%$ in hare, and by only $74 \%$ in partridges, being a species less dependent on aridizations during the vegetative period (fig.5). 


\section{Conclusions}

After a period of depression in the hare population, there is an upward increase from year to year in both spring and autumn population number and these increase are much higher $(29 \%$ and $27 \%$ correspondingly) at the initial stages of the population cycle and decrease considerably (4.8\% and 5.5\% respectively), when the population reaches maximum values, approaching the support capacities of ecosystems.

The partridge after the numerical depression in 2004-2010 registered a numberic increase (79\%) in 2017, after which the reproductive stock of the species remained at 43-55 thousand pairs with a slight upward trend in the next years.

The pheasant population demonstrates an increase in the dynamics of the acclimatization process, when the annual increases ranged between $37 \%$ (under stressful arid conditions) and $103-126 \%$ under favorable conditions.

\section{Bibliography}

1. Munteanu A., Savin A., Corcimaru N., Sâtnic V. Starea populaţiilor unor specii de animale de vânătoare în R. Moldova. Culegere "Diversitatea, valorificarea rațională și protecția lumii animale“ Chișinău. CEP USM. 2006 P.91-93

2. Marboutin E. Population dynamics in European hare: breeding parameters sustainable harvest rates. Journal of Applied Ecology 40, 2003. P. 580-591.

3. Savin A., Ciocoi O., Caisîn V., Sîtnic V. Dinamica efectivelor principalelor specii de vânat în republica Moldova. Materialele Conferinței Internaționale "Mediul și schimbarea climei: de la viziune la acțiune”. 5-6 iunie 2015. Chişinău. P. 231-235.

4. Savin A., Ciocoi O. Dinamica efectivului populației iepurelui de camp (Lepus europaeus) în Republica Moldova și expluatarea ei cinegetică. /Materialele Simpozionului Internaţiuonal dedicate aniversării a 100 ani a academicianului Alexei Spassky. 13 octombrie 2017, Chișinău, p. 405-412.

5. Savin A., Caisîn V., Grosu Gh. Dinamica efectivelor şi impactul unor prădători în ecosistemele Republicii Moldova. /Materialele Simpozionului Internaţiuonal dedicate aniversării a 100 ani a academicianului Alexei Spassky. 13 octombrie 2017, Chișinău, p. 403-404.

6. Wieren Sipke E., Wiersma Marjolein, Prins Herbert H.T. Climatic factors affecting a brown hare (Lepus europaeus) populations. Lutra. 2006, 49, No 2, p. 103-110.

7. Кудрявцева Т.В. Роль климатических факторов в размещении населения и динамике численности зайца-русака (Lepus europaeus Pall.) на юге Средней Сибири / Вестник Крас ГАУ. Вып. 3. Красноярск, 2008, с. 148-153. 